\title{
Archivo, Cine, Política: Imágenes Latentes, Restos y Espectros en Films Argentinos y Chilenos
}

\author{
Archive, Cinema, Politics: Latent Images, Remnants \\ and Phantoms in Argentinean and Chilean films
}

\author{
Wolfgang Bongers \\ Universidad Católica de Chile \\ wbongers@uc.cl
}

Resumen • En este trabajo, Imagen latente (1987) de Pablo Perelman servirá de meseta para desarrollar algunos nexos entre cine, estética y política. Las imágenes del film son líneas de fuga que me llevarán, desde el inicio, a hablar del archivo y del resto con relación a lo ocurrido durante las dictaduras en Chile y Argentina, considerando los impulsos totalitaristas que las preceden en Europa. De ahí la pertinencia de hablar del espectro en su relación con el cine y su futuro, la memoria y el fenómeno de la desaparición. El texto establecerá, de esta manera, resonancias con otros restos y objetos, tanto europeos como argentinos y chilenos, entre ellos films de Alain Resnais, El ausente (1987) de Rafael Filipelli, Los rubios (2003) y Restos (2010) de Albertina Carri, y los libros El palacio de la risa (1995) y Lazos de familia (2001) de Germán Marín. La idea es enfatizar la relación del archivo, de sus diversas tecnologías y materialidades, con la política y el arte cinematográfico en su capacidad de crear relaciones necesarias e inesperadas entre las imágenes mentales y las imágenes-objetos que configuran —o desfiguran—la existencia.

Palabras clave: Cine chileno y argentino, archivo y cine, remanentes, imágenes y fantasmas.

Abstract - The following article will use Imagen latente (1987) by Pablo Perelman to develop a few links between Cinema, Aesthetics and Politics. It will consider the film's images as vanishing lines that will lead us to discuss the archive and the remnants in relation to the time lived by Chile and Argentina during their military dictatorship. For this, the article will consider the totalitarian impulses found in Europe. In this light, it will become relevant to discuss the notion of phantom, in relation to cinema, memory, and the phenomenon of disappearance. Thus, the text will establish resonances with other fragments and objects from Europe, Argentina and Chile, such as the films by Alain Resnais, El ausente (1987) by Rafael Filipelli, Los rubios (2003) and Restos (2010) by Albertina Carri, as well as the books El palacio de la risa (1995) and Lazos de familia (2001), by Chilean writer Germán Marín. Through this discussion, the article will try to emphasize the notion of archive, given its diverse technologies and materiality, by means of the politics and the art of cinema, considering their capacity to create necessary and unexpected links between mental and objectual images that configure - or disfigure - existence.

Keywords: Chilean and Argentinean film, archive and cinema, remnants, images and phantom. 
Y lo omitido ronda, tan grande como los espectros del futuro

Paul Celan, Amapola y memoria

El desastre está del lado del olvido; el olvido sin memoria, el retraimiento inmóvil de lo que no ha sido trazado - lo inmemorial quizás: recordar por olvido, el afuera de nuevo.

Maurice Blanchot, La escritura del desastre

El sensorium del arte es siempre un «sentido común» paradójico, un sentido común disensual, hecho de acercamiento y de distancia.

Jacques Rancière, Sobre políticas estéticas

\section{ARCHIVOS}

Pensar el cine y la memoria desde el archivo y desde el espectro. Empecemos, pues, con el archivo. «El archivo oscila entre un cementerio de hechos y un jardín de ficciones» $(\text { Ernst, } 60)^{1}$ Esta frase de Ulrich Raulff, actual director del archivo de literatura alemana de Marbach, el más importante del país en su materia, es citada por Wolfgang Ernst, arqueólogo de los medios en la Universidad de Humboldt de Berlín, en su libro El ruido de los archivos (2002). Ernst realiza una aproximación al archivo considerando las teorías elaboradas en Francia por Michel Foucault, Arlette Farge y Jacques Derrida, pero modificando la perspectiva epistemológica y deconstructivista hacia una teoría de los medios y sus materialidades. En este sentido, habla del punto ciego de Foucault: a pesar de que el archivo es definido en La arqueología del saber como un sistema virtual de la formación y de la transformación de los enunciados en determinadas circunstancias históricas y culturales, Foucault conceptualiza el archivo como biblioteca, lugar de almacenamiento y catalogizaciones del saber en el que, de hecho, encuentra los textos que analiza. ${ }^{2}$ Pero los medios electrónicos y digitales, y los circuitos cibernéticos, según Ernst, llevan a un borramiento virtual de la diferencia entre archivo, biblioteca y museo en el concepto de «información». Con esto, la cultura de almacenaje se habría transformado en una cultura de los medios de transmisión. Aspecto que también subraya Jacques Derrida en su libro sobre el archivo y el psicoanálisis: «No hay archivo sin un lugar de consignación, sin una técnica de repetición y sin una cierta exterioridad. Ningún archivo sin afuera» (Derrida, Mal de archivo, 19). Y por eso, señala algo más adelante,

Todas las citas del libro de Ernst, publicado en alemán, son traducidas por el autor de este artículo.

Toute la mémoire du monde (1956), un corto de Alain Resnais, es un testimonio irónico sobre la memoria acumulada en el archivo monstruoso que es la Biblioteca Nacional de Francia. Un comentarista acompaña el registro en un travelling lento de los sótanos, pasillos y salas de la Biblioteca y explica esta memoria imposible al comienzo del film: «Ante sus almacenes llenos hasta explotar, los hombres empiezan a tener miedo, miedo de estar inundados por esta multitud de escritos, por esta armada de palabras; pues, para garantizar su libertad, construyen fortalezas». La biblioteca, aquí, no es la memoria cultural, al contrario, es su prisión, su laberinto, producto del miedo ante la amnesia total. Y no podemos dejar de pensar, en este contexto, en el Funes de Borges. 
la estructura técnica del archivo archivante determina asimismo la estructura del contenido archivable en su surgir mismo y en su relación con el porvenir. La archivación produce, tanto como registra, el acontecimiento. ${ }^{3}$ Ésta es también nuestra experiencia política de los medios llamados de información. Ello significa que en el pasado el psicoanálisis (no más que tantas otras cosas) no habría sido lo que fue si el E mail, por ejemplo, hubiera existido. Y en el porvenir no será ya lo que Freud y tantos psicoanalistas han anticipado, desde que el E mail, por ejemplo, se ha hecho posible (Mal de archivo, 24). ${ }^{4}$

El archivo es, entonces, una suerte de «matriz prefigurada de la realidad registrada» (Ernst, 24). En el texto de Derrida, sin embargo, resuenan no sólo las tempranas observaciones de Walter Benjamin en El narrador (1936) sobre la pérdida de experiencia en la primera Posguerra europea que coincide con el auge de la era de la «información» en los medios masivos de comunicación, sino también la conclusión de Deleuze en el segundo tomo de sus Escritos sobre cine (1985), cuando dice que en el mundo moderno «la información reemplaza a la Naturaleza» (Deleuze, 352), para luego vaticinar el futuro del archivo de imágenes y pensamientos que es el cine $^{5}$ : «La vida o la supervivencia del cine dependen de su lucha interior con la informática» (359).

De todas maneras, es ambiguo entender el archivo como metáfora universal para las técnicas culturales, porque los archivos no son esencialmente parte de la memoria cultural. ${ }^{6}$ Recién desde los comienzos de la historiografía moderna alrededor de 1800, los materiales administrativos y políticos de los archivos para ejercer el poder son transformados en fuentes para contar historias: «En el momento en que el archivo se convierte en «incomparable fuente de tradición histórica), ya ha perdido su función de ser memoria justiciable respecto del almacenamiento del poder» (Ernst, 69). La idea del archivo como contenedor de datos para construir historias y memorias, se ha desplazado, en la teorización contemporánea, hacia la concepción de archivos dinámicos que forman parte de sistemas complejos e interrelacionados de memorias, seres humanos, organizaciones y máquinas, en un juego permanente de des- y re-contextualizaciones. Lo que cuenta, entonces, es el proceso del archivo entre recuerdo y olvido, entre figuración y desfiguración de memorias, en lo plural, y no tanto en el objeto singular de una memoria individual o colectiva. Aquí está el valor del archivo como metáfora: su función de participar en procesos de traslado, traducción y transmisión de datos, imágenes, textos, entre sujetos y culturas. Y aquí se divisan también algunas características de las prácticas artísticas que nos interesan, y quiero citar en este respecto una observación de Jacques Rancière sobre las políticas estéticas:

Las prácticas del arte in situ, el desplazamiento del cine en formas espacializadas de la instalación museística, las formas contemporáneas de espacialización de la música o las prácticas actuales del teatro y de la danza van en la misma dirección: la de una desespeci-

\footnotetext{
En el contexto de la relación entre el archivo, la ruina, las técnicas de inscripción y el museo como institución del olvido activo, cfr. también Déotte: «Es la repetición la que hace ser: no hay acontecimiento sin superficie de inscripción. La nación, sus teatros de memoria, su historiografía, sus museos, sus escuelas, constituyeron esa superficie de inscripción» (Déotte, 23-24).

4 En analogía a la jerga informática y en relación a las nuevas tecnologías y las nuevas formas de comunicación como el E-mail, podríamos decir que es cada vez más importante la RAM (Rapid Access Memory), la memoria de acceso aleatorio, de transmisión directa entre procesos de lectura y escritura, frente a la ROM (Read Only Memory), la memoria almacenada de solo lectura.

5 Los cineastas, según Deleuze, piensan con imágenes, mientras que los filósofos piensan con conceptos. Cfr. Aguilar 2008.

6 Cfr. Spieker 2008
} 
ficación de los instrumentos, materiales o dispositivos propios de las diferentes artes, la de la convergencia hacia una misma idea y práctica del arte como forma de ocupar un lugar en el que se redistribuyen las relaciones entre los cuerpos, las imágenes, los espacios y los tiempos (Rancière, 17).

Ahora bien, si pensamos más concretamente en las experiencias de violencia, tortura, injusticia, sufridas por pueblos, comunidades e individuos en América del Sur, y en las formas que han pretendido representar estas experiencias, es preciso abrir la monstruosidad del archivo 7 a su dimensión ética, tal como lo propone Giorgio Agamben en su libro sobre el archivo y el testigo en Auschwitz, nombre y monumento más evidente del exterminio sistemático del pueblo judío e indiscutible no-símbolo del fracaso del proyecto de la modernidad del mundo occidental; no-símbolo, porque lo que está en juego respecto del Holocausto es precisamente la «representabilidad»—el valor simbólico- de un acontecimiento que borra toda posibilidad de ser re-presentado. ${ }^{8}$ Agamben, pues, se pregunta quién estaría en condiciones de dar cuenta y de decir lo indecible, lo monstruoso del archivo. La figura del testigo integral, que Agamben encuentra en los textos de Primo Levi, no es menos paradójica que el concepto del archivo. ${ }^{9}$ Lo no-dicho, lo norepresentable, lo innombrable, está en un archivo que nunca será accesible hasta llegar a la vivencia misma de lo imposible, y esta vivencia inhibe la enunciación, remite a un afuera, un lugar en el que los enunciados no son posibles. El objetivo de la escritura de sobrevivientes como Primo Levi o Jean Améry, no obstante, es el recuerdo en su función de prevenir similares experiencias en el futuro: el «nunca más», enunciado que se encuentra en la base de los monumentos, sitios y museos que recuerdan la represión y la violencia a los derechos humanos ocurridos durante los totalitarismos y dictaduras del siglo XX en numerosas regiones del mundo.

Todo esto conduce, en cualquier caso, a una incomodidad irremediable porque, en la lógica de la paradoja recién mencionada, todo discurso sobre la memoria —-textual o

Derrida advierte: «El archivo es una violenta iniciativa de autoridad, de poder, es una toma de poder para el porvenir, pre-ocupa el porvenir; confisca el pasado, el presente y el porvenir. Sabemos muy bien que no hay archivos inocentes» («El cine y sus fantasmas»).

8 Partiendo de lo dicho por Adorno en su Dialéctica negativa (1966) y otros escritos, es una discusión de largo aliento a la cual volveremos. Para un panorama de la cuestión desde varias perspectivas epistemológicas, cfr. las contribuciones al libro editado por Saul Friedlander, En torno a los límites de la representación. El nazismo y la solución final (la versión original es de 1992), y también la propuesta de Jean-Luc Nancy, La representación prohibida (2006), donde el autor vincula toda representación a una «división de la ausencia, que se escinde, en efecto, entre la ausencia de la cosa (problemática de su reproducción) y la ausencia en la cosa (problemática de su representación)» (39).

9 Tomando en cuenta la función del enunciador y ampliando la conceptualización foucaultiana, Agamben, como es sabido, define el archivo como «sistema de las relaciones entre lo no dicho y lo dicho»: «El archivo es, pues, la masa de lo no semántico inscrita en cada discurso significante como función de su enunciación, el margen oscuro que circunda y delimita cada toma concreta de palabra. Entre la memoria obsesiva de la tradición, que conoce solo lo ya dicho, y la excesiva desenvoltura del olvido, que se entrega en exclusiva a lo nunca dicho, el archivo es lo no dicho o lo decible que está inscrito en todo lo dicho por el simple hecho de haber sido enunciado, el fragmento de memoria que queda olvidado en cada momento en el acto de decir yo» (Agamben, 151). En todo caso, cabe señalar aquí el hecho que las observaciones de Agamben se mueven en un contexto que relaciona la noción del archivo con la del testimonio como «sistema de las relaciones entre el dentro y el fuera de la langue, entre lo decible y lo no decible en toda lengua; o sea, entre una potencia de decir y su existencia, entre una posibilidad y una imposibilidad de decir» (Agamben, 151-152), cuya figura central en el libro es el musulmán de los campos de concentración nazis que se convierte precisamente, siendo «testigo integral» de lo imposible, en «resto» paradójico de la función enunciativa que responde a la pregunta "¿Cómo puede un sujeto dar cuenta de su propia disolución?» (151), en circunstancias (Auschwitz) que pretenden eliminar el sujeto y su potencia enunciativa. 
audiovisual- es injusto. Asumir este abismo y aceptar este momento paradójico de la justicia injusta, es lo que nos permite hablar sobre el complejo entramado de relaciones entre los archivos y las estrategias, estéticas y políticas de (anti)memoria presentes en algunas imágenes que reflexionan sobre los acontecimientos en Chile y Argentina durante las últimas décadas. ${ }^{10}$

\section{RESTOS}

Continuemos con dos restos. ${ }^{11}$ Uno es el último corto de Albertina Carri que precisamente se llama Restos (2010, 8'), un trabajo hecho en el marco del proyecto bicentenario « 25 miradas, 200 minutos». ${ }^{12} \mathrm{Al}$ comienzo del film, un plano medio en toma fija muestra a un hombre desnudo y agachado entre los árboles de una selva. El hombre realiza movimientos que recuerdan ritos arcaicos o los movimientos de un animal. La voice over de Analía Couceyro, actriz que en Los rubios (2003) representa a la directora Albertina Carri y que es protagonista en La rabia (2008), enuncia en voz grave, decidida, sin vacilaciones: «Acumular imágenes, ¿es resistir? ¿Es posible devolverles ahora el gesto desafiante?» (Carri, Restos). Esta primera secuencia, que apunta inmediatamente al archivo (acumulación) y a un gesto (resistir), provoca dudas sobre lo que se verá y se escuchará en el film ${ }^{13}$, sobre lo que tiene que ver la imagen del hombre desnudo en la selva con el tema del corto, la memoria nacional en el bicentenario de la Independencia. Es una inquietud que pronto se plasmará en la siguiente pregunta: ¿qué es lo que ha quedado de un cine político, comprometido, desafiante durante los años sesenta y setenta, reprimido y destruido por la dictadura militar entre 1976 y 1982, y que, treinta años después, no tiene visibilidad en la vida pública? La segunda secuencia muestra, en primer plano y con mu-

10 Desde una crítica radical hacia las estrategias y tecnologías del olvido y del consenso en el Chile postdictatorial de la Transición, Nelly Richard reclama un trabajo de memoria activa que considere las fisuras, los quiebres y tormentos que necesariamente atraviesan el acto del recuerdo, tanto en el campo intelectual como en el campo artístico: «La memoria es un proceso abierto de reinterpretación del pasado que deshace y rehace sus nudos para que se ensayen de nuevo sucesos y comprensiones. La memoria remece el dato estático del pasado con nuevas significaciones sin clausurar, que ponen su recuerdo a trabajar, llevando comienzos y finales a reescribir nuevas hipótesis y conjeturas para desmontar con ellas el cierre explicativo de las totalidades demasiado seguras de sí mismas» (Richard, 31). De ahí que se insertan en el libro los discursos de intelectuales y artistas como Tomás Moulian, Alberto Moreiras, Ernesto Laclau, Beatriz Sarlo, Hugo Vezzetti; Diamela Eltit, Carlos Altamirano, Eugenio Dittborn.

11 Queremos establecer resonancias asimétricas y abiertas a diferentes figuraciones del campo cinematográfico europeo y latinoamericano con el concepto de «resto» tal como lo desarrolla Giorgio Agamben respecto de las relaciones complejas entre sujeto, testimonio, lengua y poesía (arte): «el resto de Auschwitz -los testigos- no son ni los muertos ni los supervivientes, ni los hundidos ni los salvados, sino lo que queda entre ellos» (Agamben, 160).

12 Es un proyecto financiado por la Secretaría de Cultura de la Presidencia de la Nación, en cooperación con la Universidad Nacional de Tres de Febrero. El corto puede verse aquí: <http://www.youtube.com/ watch? $=7 \mathrm{QFkC}$-vsqwY>.

13 Para enmarcar los análisis de estas y otras imágenes conviene recordar la distinción pragmática que hace Serge Daney, en su ensayo «Antes y después de la imagen» (Daney, 269-276), entre lo visual («verificación óptica de un procedimiento de poder - ya sea tecnológico, político, publicitario o militar-, procedimiento que solo suscita comentarios claros y transparentes») y la imagen («experiencia de la visión» en varias capas de sentido y considerando específicamente la alteridad como característica fundamental de esta experiencia), esto en el contexto de una reflexión sobre la mediatización de la guerra del Golfo, en 1991. 
cha intensidad táctil, algunos rollos de celuloide en llamas: los archivos cinematográficos destruidos. Luego las imágenes se desplazan hacia un archivo de rollos intactos, amontonados y abandonados en una casa, que la cámara muestra en un travelling lento, muy cercano al material fílmico. La voz de Couceyro las acompaña y habla de esas películas perdidas ${ }^{14}$ que no buscaban espectadores, sino «militantes que las verían en sindicatos, escuelas, centros vecinales, iglesias, universidades, incluso en la intemperie, en el corazón de las villas» (Carri, Restos). Después cambia la escena y la cámara muestra el trabajo de un cineasta-restaurador que corta, monta, proyecta y observa algunas imágenes no identificables, huellas de colores y sonidos en movimiento. Mientras que se ven imágenes superpuestas, cada vez más desquiciadas, del trabajo del cineasta y del material fílmico con el que trabaja, la voz, siempre en forma insistente, adquiriendo un tono melancólico y poético, habla de la «máquina de amputar del terrorismo de Estado» que mutiló o destruyó estos films, «trofeos de una guerra que también se jugó en el imaginario.» De todo este material se salvaron pocas imágenes, y la mayoría, como señala el comentario, «quedaron perdidas, desaparecidas ellas también» (Carri, Restos). Este «también»al final de la frase remite sin rodeos a la desaparición irrecuperable de personas e imágenes ocurrida durante la lucha política.

Algunos instantes después, Carri utiliza los rollos de celuloide para crear formas extrañas con ese material, artefactos que se mueven por el espacio filmado, que se disuelven y se transforman en líquidos y vapores. La voz habla de las películas que sobrevivieron y que «recuperaron la firma del autor, aunque así no fueron pensadas». Más bien adquirieron una «identidad colectiva para empuñar la cámara» y generar una

potencia de la acción colectiva. ${ }^{15}$ Decir nosotros tenía la fuerza del agua que busca la pendiente. Desde esta orfandad, que solo puede decir yo, me dejo encandilar por las imágenes perdidas. Buscarlas es resistir a esta intemperie sin sueños. Enhebrar secuencias para empujar los flashes sueltos de la memoria. ¿Será posible recuperar su gesto desafiante, su potencia vital, su exquisito presente hinchado de futuro? ¿Podrán todavía mellar la trama que cubría el cielo de los rebeldes? El fulgor de su ausencia quema. Ahora mismo (Carri, Restos).

Carri muestra otros juegos de color que se mueven por el espacio fílmico, que se expanden y se mezclan en un baño de agua. Son imágenes poéticas que se entrelazan con la poesía melancólica de las frases enunciadas. Un corte, finalmente, permite saltar a la situación del comienzo: la cámara muestra al hombre desnudo en la selva, ahora en otro lugar y en otra postura. Dice la voz: «Acumular imágenes es una forma de la memoria. Volverlas disponibles es necesario para desbrozar la huella por la que seguir andando.»

14 Daniel Link, escritor y académico argentino, en una conferencia del coloquio internacional «Archivos de la memoria 1970-2010", celebrado entre el 22 y el 25 de septiembre de 2010 en la Facultad de Letras de la Universidad Católica de Chile, señala que estas películas aludidas en el film de Carri pertenecerían, antes que al "Cine Liberación» de Fernando Solanas y Octavio Getino (cfr. Solanas, Fernando y Getino, Octavio, Cine, cultura y descolonización, Buenos Aires: Siglo XXI, 1971; Getino, Octavio, Cine y dependencia. El cine en la Argentina, Buenos Aires: Puntosur, 1990), al «Cine de la Base», de Raymundo Gleyzer y Pablo Szir, los dos desaparecidos en 1976 (cfr. Peña, Fernando Martín y Vallina, Carlos, El cine quema, Buenos Aires: de la Flor, 2002). Hay varios trabajos de este grupo en youtube, por ejemplo fragmentos de Los traidores (1973), del mismo Gleyzer.

15 Un ejemplo chileno de película colectiva que luego toma nombre de autor, es el documental corto Recado de Chile (1979), filmado en la clandestinidad y censurado en Chile, cuyos directores ahora se disputan el título. 
En Restos, como archivo meta-cinematográfico ${ }^{16}$, el telón de fondo son la desaparición y la muerte, de las personas, de grupos políticos de resistencia, del cine político radical de los años sesenta y setenta. La recuperación de esas imágenes desaparecidas es, también, una forma de recuperación de las vidas, los cuerpos y rostros de las personas desaparecidas en los años previos y durante las dictaduras en Argentina y en Chile. Cuando Carri desliza la materialidad fílmica de Restos hacia esas esculturas plásticas, poéticas y táctiles en movimiento, es un gesto que lleva a pensar en el cine experimental de los años veinte, de un Man Ray, un Hans Richter o un Marcel Duchamp. Sin embargo, en el contexto cultural y político en el que se inserta el film de Carri, y tomando en cuenta el comentario programático de la voz que reivindica un trabajo en y con el archivo de imágenes cinematográficas como forma de memoria, los Restos son, precisamente, lo que quedará.

El otro resto al que queremos hacer referencia es una imagen-objeto de un archivo personal que también pone en escena la desaparición de personas e imágenes durante el período de los 70, esta vez en Chile:

\section{¿DONDE ESTA EL PAPA ...?}

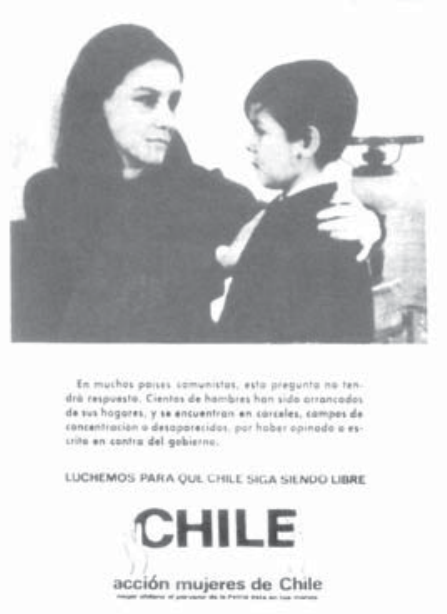

Lo fantasmático de esta imagen-objeto de 1970 es el desfase perceptivo y temporal que provoca: parece referirse a varios estratos de memoria de un pasado desdoblado, un pasado que es un futuro inmediato: “¿Donde está el papá?», (¿dónde está la mamá, la hermana, el hermano, la hija, el hijo?). Esta pregunta, en el contexto en el que la encontramos, se refiere a dos momentos políticamente opuestos, entre 1970 y 1973, entre el

16 Y si pensamos en los procesos de digitalización en todos los niveles de producción, distribución y recepción de los artefactos cinematográficos en los tiempos que corren, Restos también es un archivo postcinematográfico. Para un análisis de esta situación del cine cfr. Cherchi Usai (2005), Manovich (2006), La Ferla (2009), y el ensayo «La imagen discreta» de Stiegler en Derrida/Stiegler» (1998). 
ascenso por vía democrática del gobierno marxista-leninista de Salvador Allende y el golpe militar de Augusto Pinochet. La frase es potencialmente enunciada por representantes enfrentados desde polos antagónicos durante la lucha política que tiene lugar en Chile, y esta lucha también es una lucha por la imagen justa. ${ }^{17}$

La imagen-objeto es originalmente un aviso publicitario y forma parte de una campaña antimarxista de la «acción mujeres de Chile», financiada por la CIA. En el texto de letra más chica se denuncia la persecución y desaparición de los hombres en países comunistas, y se promueve la lucha por un Chile libre, dando por sentada la amenaza que significa la candidatura del socialista Salvador Allende a la Presidencia, tanto para los poderes nacionales de derecha como para los poderes neoliberales del exterior, específicamente Estados Unidos, horrorizado por el desarrollo de la Guerra Fría que ya había generado varios momentos y escenarios de mucha tensión: Cuba, Berlín, Vietnam, por solo mencionar algunos de los más visibles. Ahora bien, este aviso proviene de un archivo personal hecho público: se trata del archivo del escritor chileno Germán Marín, exiliado durante 19 años, en México y Barcelona, autor de la voluminosa trilogía de novelas Historia de una absolución familiar ${ }^{18}$ y otros libros cuyo eje es la memoria personal y colectiva en relación a su país natal. Marín publica, en 2001, Lazos de familia. Relatos con imágenes, un libro en el que entra en diálogo con un "conjunto bastante disímil de materiales gráficos tales como fotografías, recortes de prensa, documentos, tarjetas postales, etc., extraídos al azar de distintas fuentes, algunos gracias a los viajes» (Marín, 13). Al enfrentarse a este archivo heterogéneo, la escritura de Marín trata de ordenar y dilucidarlo en abordajes subjetivos que sitúan los objetos gráficos en contextos históricos y políticos. Con esto crea retazos de memoria individual y colectiva, sin cierre o coherencia totalizante; al contrario, antes de publicar el libro el autor había realizado, en un proceso de varios años, una selección de las imágenes, una edición del material, un montaje que le permitía escribir lo que quería decir sobre un pasado y un futuro de Chile de los que forma parte como intelectual de izquierda, como escritor exiliado y retornado. Por lo tanto, se mezclan en el libro-archivo afiches de películas, fotos de mujeres en poses eróticas de distintas épocas, la página de un comic, fotos del Santiago antiguo, avisos publicitarios, una foto de Marín con sus amigos Enrique Lihn y Cristián Huneeus, hecha en 1971 en Santiago, y varias imágenes con claras referencias a la realidad política, la violencia e injusticia que se vive en el país durante la dictadura. Deseo y felicidad, violencia y política son las categorías bajo las que se agruparían las imágenes-objeto del libro.

Ahora bien, es interesante que Marín titula su reflexión sobre el aviso publicitario «Lecciones de la mentira». Dice que «nada hacía pensar que, pocos años después, la frase de dicho anuncio, publicado en diversos medios periodísticos, dentro de una seguidilla

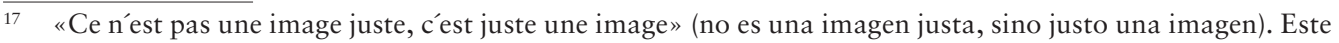
notorio juego de palabras de Jean-Luc Godard en un cartel del film experimental Vent d'est (1969), del Grupo Dziga Vertov, en el que también aparece Glauber Rocha en una escena, es discutido por Pascal Bonitzer en "¿Qué es un plano?», en El campo ciego (1982). En esa "fórmula extraña y simplemente bella que parece oscilar en el límite del puro sinsentido", Bonitzer ve una «reducción caricaturesca» de la proximidad de la teoría y de la práctica del cine, apuntando a que «en un film no se trata solo de imágenes, justas o no, sino de una realidad más o menos trucada, montada u ordenada, en la mayoría de los films, en escenas, en secuencias, y, metonímicamente, en planos» (10). Ana Amado (2009) retomará el juego en su sentido ético y estético en el título de su libro sobre la imagen justa en el cine argentino entre 1980 y 2007.

18 Editorial Sudamericana 1994, 1997, 2005. 
de otros motivos no menos intoxicantes, tendría una articulación real en nuestra sociedad y se expresaría, bajo el imperio del miedo, en muchos hogares.» A Marín le interesa el paso de la mentira vergonzosa a una verdad de terror, "producto de las burlas que la historia hace a una generación y a otra» (Lazos de familia, 25). Pero también es notable el potencial de imágenes latentes que genera este objeto de archivo. En su libro sobre los ruidos de los archivos, Wolfgang Ernst señala que es importante «revelar las latencias del archivo, es decir, lo que se hace palpable en la presencia del archivo como ausencia, tal como opera el negativo fotográfico» (Ernst, 29)19. El archivo personal de Marín, hecho público y visible a través del libro Lazos de familia, pone en escena esta latencia de una ausencia palpable en la representación como "presencia presentada, expuesta o exhibida. No es entonces la pura y simple presencia: no es, justamente, la inmediatez del ser-puesto-ahí, sino que saca a la presencia de esa inmediatez, en cuanto la hace valer como tal o cual presencia» (Nancy, 37). En este sentido, la imagen-objeto del libro de Marín se vuelve fantasmática. Hugo Vezzetti, en su libro sobre los efectos sociales de las luchas armadas y la dictadura militar de los años setenta en Argentina, que, mutatis mutandis, distarían poco de lo que pasó en Chile, señala la importancia de «una suspensión, un borramiento de las representaciones manifiestas como una condición para la rememoración de las escenas latentes» (Vezzetti, 36). Vezzetti subraya los alcances del psicoanálisis «para introducir las complejidades y las paradojas del recuerdo y el olvido» y pregunta: «¿Qué es olvidar, sino abrir un tramo y un espacio virtual de recuerdo, justamente porque eso que no está presente, que no es vivido ni pensado está latentemente disponible para ser evocado, confrontado, incluso discutido o rectificado por un acto de memoria?» (36)

Las imágenes latentes, generadas en el espacio dialéctico entre imagen mental e imagen-objeto, adquieren especial importancia en el cine, ya que el haber-estado-ahí y el eso-ha-sido de la fotografía (Barthes) remite más al presente de un pasado que experimentamos como ausencia que a la presencia ausente del presente que muestra el cine como arte temporal de una repetición espectral. Conviene recordar, en este contexto, unas frases de Derrida sobre cine y psicoanálisis:

La experiencia cinematográfica pertenece de cabo a cabo a la espectralidad [...] Todo espectador, durante una función, se pone en contacto con un trabajo del inconsciente que, por definición, puede ser asimilado al trabajo de la obsesión [hantise] según Freud. Él llama a esto experiencia de lo que es «extrañamente familiar» [unheimlich]. [...] psicoanálisis y cinematografía, son en verdad contemporáneos; numerosos fenómenos ligados con la proyección, con el espectáculo, con la percepción de ese espectáculo, poseen equivalentes psicoanalíticos $[\ldots]$ («El cine y sus fantasmas»).

Con todo, el dispositivo cinematográfico, como experiencia y estructura fantasmal, se sitúa entre visibilidades e invisibilidades, entre registros visuales y auditivos, entre presencias y ausencias, entre pasado y futuro, entre vida y muerte. ${ }^{20}$ Pero Derrida agudiza su reflexión y la conduce hacia la relación del cine con los procesos mnémicos: «Memoria

19 Lo negativo, en términos matemáticos, es un (-), y la noción de restos, si se ve desde la matemática, también es el (-), el restar, lo que resta. Agradezco esta analogía entre procesos matemáticos y fotográficos, como también varias ideas surgidas en conversaciones sobre los ejes del presente artículo, a Ximena Vergara.

20 Sobre la ambigüedad y la indeterminación de la estructura fenomenológica del dispositivo cinematográfico cfr. también las reflexiones de Barthes (1986), Metz (2001) y Morin (2001). 
espectral, el cine es un duelo magnífico, un trabajo del duelo magnificado. Y está listo para dejarse impresionar por todas las memorias luctuosas, es decir, por los momentos trágicos o épicos de la historia» (Derrida, «El cine y sus fantasmas») ${ }^{21}$. Con estas observaciones llegaremos a otros restos fotográficos y cinematográficos.

\section{IMÁGENES LATENTES ${ }^{22}$}

¿Qué sucede, entonces, si la lógica y la memoria del espectro se cruzan en el cine con el tema de la violencia, la desaparición y la muerte de personas en sistemas autoritarios y dictatoriales?23 Pero pensemos esta relación primero desde el otro lado del espectro. Los totalitarismos que se instalan entre los años veinte y cuarenta del siglo XX en Italia, la Unión Soviética, Alemania y España, contaban con un dispositivo cinematográfico y, en general, mediático, en pleno esplendor. La radio y el cine son las tecnologías que más impactaron en la instrumentalización de los medios, llevada a cabo por los poderes fascistas en sus maniobras propagandísticas y guerristas. Un ejemplo: en la estética de Leni Riefenstahl —recordemos solamente El triunfo de la voluntad (1934)— confluyen los preceptos de sus precursores expresionistas en Alemania ${ }^{24}$ y las grandes teorías del montaje y del movimiento elaboradas en la Rusia revolucionaria, por Eisenstein y Vertov principalmente; pero aquí, con los avances tecnológicos del cine, son llevadas a un grado de perfección escalofriante al poner en escena un nuevo heroísmo cinematográfico y una

21 Cfr. al respecto el capítulo «Espectrografías» del libro Ecografías de la televisión, en el que dialogan Derrida y Stiegler sobre la lógica del espectro, relacionada al film Ghostdance (1983), de Ken McMullen, en el que aparecen la deconstrucción, la espectralidad y el mismo Derrida, quien comenta: «Un espectro es a la vez visible e invisible, a la vez fenoménico y no fenoménico: una traza que marca de antemano el presente de una ausencia. La lógica espectral es de facto una lógica deconstructiva.» (Derrida/Stiegler, 147). En «La imagen discreta», ensayo incorporado en el mismo libro, Stiegler retoma la idea de Derrida para discutirla en un marco histórico-tecnológico de la representación y la relaciona a una «historia de un defecto de origen»: «este defecto de origen nos atormenta. Nos atormenta como un fantasma (fantôme): es el fantasma. Los fantasmas (fantômes) de que hablo aquí, se trate del de la fotografía como eso ha sido, de las nuevas formas de fotografía, de los fantasmas que se encuentran en las imágenes digitales llamados 〈de síntesis〉 y en toda forma de representación, que siempre es fantasmal (fantomale), todos esos fantasmas no son más que figuras, representaciones [...] de esa falta que hace falta. Hace falta, dado que es el dinamismo mismo de toda esta maquinaria que desarrollamos y nos hace vivir; hace que queramos, deseemos, temamos, amemos, etcétera. Esa falta es una falta de memoria» (196).

22 Dice Stiegler: «La imagen en general no existe. Lo que se llama imagen mental y lo que yo denominaré aquí imagen-objeto, siempre inscrita en una historia, una historia técnica, son dos caras de un único fenómeno [...] la imagen mental siempre es el retorno de alguna imagen-objeto, su remanencia - como persistencia reteniana lo mismo que como aparición alucinatoria del fantasma-, efecto de su permanencia. Más: no hay ni imagen ni imaginación sin memoria, ni memoria que no sea originariamente objetiva» (Derrida/Stiegler, 181-182).

23 «Eterno retorno de lo que no ha sido inscrito, de lo desaparecido, de lo sumergido. Un espíritu; es decir, un espectro. Lo que habría que llamar el espíritu, lo inmemorial, de una nación: los crímenes para edificar esta nación, en tanto no han sido inscritos» (Déotte, 30).

24 En 1947, y desde una perspectiva psicológica, Siegfried Kracauer analiza en De Caligari a Hitler (1985) la mentalidad del pueblo alemán en un análisis del desarrollo del cine alemán entre los primeros films hasta las épicas ideológicas del nacionalsocialismo. Más allá de los propios análisis, es destacable que el cine como expresión afectiva y perceptiva sirva de sismógrafo para descifrar la evolución política de un país europeo. 
nueva mitología de carácter religioso que se encarnan y se concentran en la figura del fübrer. ${ }^{25}$

A lo largo de las Guerras Mundiales y de la subsiguiente instauración y consolidación (o abolición) de los sistemas totalitarios, la producción cinematográfica alcanzó el estatus del arte popular y político por excelencia en prácticamente todo el mundo. Por otra parte, las dictaduras del Cono Sur coinciden, unos treinta años más tarde, con una profunda transformación del cine a nivel mundial. Esta transformación es el resultado de la gran crisis producida precisamente por las consecuencias desastrosas de la Segunda Guerra Mundial y el intento del exterminio del pueblo judío en los campos de concentración. El cine emprende la búsqueda de otras formas y otras imágenes, encontradas por André Bazin en la estética neorrealista en Italia, y relacionadas por Deleuze con el cambio de la imagen-movimiento a la imagen-tiempo en el cine italiano y francés de Posguerra. En Latinoamérica, durante los años sesenta, el «nuevo cine latinoamericano», con sus diversos linajes nacionales, inventa discursos audiovisuales que van independizándose de las grandes fórmulas tradicionales y desarrollan nuevas estéticas cinematográficas, entre la ficción y el documental, que entran en diálogo y tensión con las teorías y estéticas europeas y norteamericanas, y que culminan, como es sabido, en el Segundo Festival Internacional del Nuevo Cine Latinoamericano, organizado por Aldo Francia en Viña del Mar, en $1969 .{ }^{26}$ Una gran cantidad de esas iniciativas fueron abruptamente interrumpidas por los golpes militares en esos países que empujaron a muchos cineastas al exilio, y a las producciones nacionales hacia un destino precario e incierto, sobre todo si sus discursos desarticulaban los propósitos dictatoriales.

Imagen latente (1987), de Pablo Perelman, no se proyectaba oficialmente en Chile hasta 1990 por ser censurado ${ }^{27}$, pero el film circulaba en los últimos años de la dictadura en forma clandestina y habría provocado un «clima histérico», según los autores de Huérfanos y perdidos. Relectura del cine chileno de la transición 1990-1999. Ganador de varios premios, entre ellos el Premio Fipresci en La Habana 1987 y el Premio especial

25 Walter Benjamin habrá conocido este film cuando escribía su ensayo sobre la obra de arte en la era de su reproductibilidad técnica, publicado en 1936, en francés y en París. No debe extrañar, frente a tan impactante y siniestro producto de propaganda política (en términos benjaminianos: la estetización de la política), que el filósofo judío, exiliado y perseguido, busque en Charles Chaplin y Micky Mouse las figuras salvadoras y antitotalitarias para una (utópica) «iluminación profana» contra el fascismo, provocada por el cine en las multitudes europeas. Otro dato al respecto: el General Francisco Franco, bajo el seudónimo de Jaime de Andrade, escribió el argumento para Raza (Sáenz de Heredia, 1941), la superproducción española que transmite la ideología fascista y su versión sobre la Guerra Civil. En esta película de ficción conviven las estéticas del montaje desarrolladas en Rusia y algunos elementos del cine norteamericano, las puestas en escena de un Orson Welles por ejemplo, cuyo Citizen Kane se estrena en el mismo año 1941. Respecto de la «suprarrepresentación nazi» como presencia manifestada sin resto, cfr. Nancy, 45-46.

26 En Chile, el Instituto fílmico — fundado en 1955 por Rafael Sánchez_ - y la Escuela de Artes de la Comunicación (fundada en 1968) de la Universidad Católica, el Centro de Cine Experimental de la Universidad de Chile (desde 1957), la Escuela de Cine de Viña del Mar (Aldo Francia), figuras como Bravo, Chaskel, Cornejo, Kaulen, Littin, Ríos, Ruiz, Soto, se perfilan como nuevos espacios y agentes de creación cinematográfica, especialmente en el género documental. Cfr. Cavallo/Díaz 2007, Corro/ Larraín/ Alberdi/ van Diest 2007, Salinas/Stange 2008. En Argentina, más allá del «nuevo cine» de directores canonizados como Torre Nilsson, Ayala, Subiela y Antín, figuras como Fernando Birri y su Escuela de Cine documental de Santa Fe, Fernando Solanas y su «Tercer cine» o "Cine Liberación», que opera desde un peronismo contestatario, Leonardo Favio y su cine inclasificable, o Hugo Santiago con Invasión (1969), se perfilan como ejes de una nueva concepción del cine. Para un panorama crítico de la historia del cine latinoamericano, cfr. Paranaguá 2003.

27 Mouesca cita los argumentos: «La cinta es una versión parcial e interesada de la realidad que no contribuye al concepto de reconciliación y que promueve la vigencia de la teoría de la lucha de clases» (154). 
del jurado del Festival de Cine latino en Nueva York 1990, es el primer film chileno de ficción que trata y muestra explícitamente el tema de los detenidos desaparecidos en Chile. ${ }^{28}$ El film puede ser considerado un trabajo de duelo inacabado y melancólico sobre la desaparición y muerte del hermano del director durante la dictadura militar en Villa Grimaldi, importante centro de detención y tortura entre 1973 y 1978, por el que pasaron entre 4000 y 5000 detenidos, de los que más de 220 fueron asesinados..$^{29}$ En lo que sigue nos proponemos contextualizar y comentar algunos aspectos de la estética política del film - en el sentido de Rancière- y con esto destacar su notable nivel de metarreflexión que no se conforma con una denuncia de los hechos políticos del momento o una puesta en escena del duelo del protagonista, sino que problematiza el mismo proceso de producción y construcción fantasmal de memorias, tanto personales como colectivas, desde el archivo cinematográfico y fotográfico disponible en ese momento histórico del país. Esta característica, si bien el film de Perelman nace en un contexto chileno y en el último tramo de la dictadura en este país, nos llevará a relacionarlo con algunos films europeos y argentinos de la posdictadura.

En el contexto europeo de Posguerra, es inevitable mencionar a Alain Resnais, sin lugar a duda precursor en desarrollar un "cine de memoria» y una de las estéticas autorreflexivas más extraordinarias que cuestiona el mismo acto de re-presentar el pasado traumático en el cine. ${ }^{30}$ En Noche y niebla (1955) viaja con su cámara a Auschwitz para filmar ese lugar en ruinas, espantosamente tranquilo y vacío después de las atrocidades cometidas allí durante la Guerra. Resnais monta y mezcla sus propias imágenes con material fílmico y fotográfico encontrado en archivos nazis de la época, imágenes que muestran por primera vez en el cine los cadáveres amontonados y otras crueldades de los campos, acompañadas por una música compuesta por Hanns Eisler. Resnais termina el film con la pregunta desesperada por la responsabilidad colectiva respecto de estos crí-

28 Hay antecedentes contestatarios en el cine documental: Recado de Chile (1979) muestra a las mujeres (madres, hijas, esposas) que se juntan en una casa a discutir y buscar estrategias para buscar a los hombres desaparecidos. En 1983, el colectivo Cine-ojo realiza Chile, no invoco tu nombre en vano, film que muestra por primera vez las manifestaciones y protestas callejeras en contra del régimen militar, registros utilizados en varias películas posteriores. El mediometraje documental Cien niños esperando un tren (1988), de Ignacio Agüero, filma un taller de cine llevado a cabo por Alicia Vega, destacada investigadora del cine chileno, con un grupo de niños de poblaciones marginales. Varias escenas, siempre de manera sutil, critican implícita o explícitamente la situación social del país. Otro film de ficción, La estación del regreso, de Leonardo Kocking, sale en 1987 y trata el tema de la represión y desaparición, pero con estrategias más elusivas, cfr. Mouesca, 151-153; Pinto, 52. En televisión, el noticiario clandestino Teleanálisis (1984 a 1989) emitía «registros de urgencia».

29 Hoy, Villa Grimaldi es un lugar de memoria, un Parque por la Paz, un museo, un proyecto educativo y de trabajo de archivo: http://www.villagrimaldi.cl.

30 Dice Deleuze respecto de la «imagen-recuerdo» en el cine, basándose en Bergson, que ella no es virtual, sino que «actualiza por su cuenta una virtualidad (que Bergson llama «recuerdo puro»). Por eso la imagen-recuerdo no nos entrega el pasado, sino que solo representa el antiguo presente que el pasado «fue». La imagen-recuerdo es una imagen actualizada o en vías de actualización que no forma con la imagen actual y presente un circuito de indiscernibilidad» (Deleuze, 79-80). En este sentido, concluye Deleuze, «no son la imagen-recuerdo o el reconocimiento atento los que nos dan el justo correlato de la imagen óptica-sonora, sino más bien los trastornos de la memoria y los fracasos del reconocimiento» (80). Es aquí donde opera el cine de Resnais. Y en otro orden de las cosas, con Vértigo (De entre los muertos), de 1956, Hitchcock muestra, según las reflexiones fílmicas de Chris Marker (Sin sol, 1982) una memoria enloquecida, vertiginosa, en la obsesión compulsiva de la repetición de las escenas vividas y revividas del protagonista, y que, a otro nivel, repite el mismo Marker en su film sobre los mecanismos de la memoria fotográfica y cinematográfica en tiempos de nuevos formatos electrónicos. Marker retoma y repone la espiral como símbolo polisémico del film de Hitchcock que también remite al propio cine en su estructura espectral. 
menes. Noche y niebla es un ejemplo notable de una ética y estética radical, enunciada y reclamada desde el cine, que provocó una gran polémica política acerca de los efectos que causaría la proyección de este film entre los espectadores alemanes. ${ }^{31}$ En Hiroshima mi amor (1959), un trabajo en el que colabora Marguerite Duras, Resnais adopta otras estrategias. Contrasta la memoria colectiva de un desastre humano, provocado por la utilización de la bomba atómica por Estados Unidos en la ciudad japonesa al final de la Segunda Guerra Mundial, con la memoria individual de una francesa que perdió su amante alemán durante esa misma Guerra. En los primeros 15 minutos, el film pone en escena los abismos de la memoria entre recuerdo y olvido en la disyunción que provocan las palabras contradictorias enunciadas por las voces de los dos amantes, mientras que las imágenes filmadas por Resnais y el material de archivo muestran los efectos desastrosos y brutales de la bomba en los cuerpos humanos y la estructura de la ciudad devastada. El film mezcla estas imágenes con primeros planos de los cuerpos de los amantes que los detallan y deforman a la vez. En el transcurso del film, los diálogos entre la actriz francesa y el amante japonés ocupan cada vez más espacio y abren la narración sobre las experiencias traumáticas de la mujer que se introducen a través de varios flashbacks. Hiroshima mi amor pone en tensión los hechos y dichos filmados; en este sentido, son las disonancias que generan una puesta en abismo de la representación cinematográfica de la memoria individual y colectiva. ${ }^{32}$

Otro hito en la representación cinematográfica de la memoria traumática, individual y colectiva, tajantemente opuesta a las estrategias de Resnais es sin duda Shoa (1985), film iconoclasta con una duración de más de nueve horas en el que Claude Lanzmann renuncia programáticamente a mostrar cualquier documento de archivo u otras imágenes que muestren el horror de los campos. ${ }^{33}$ Lanzmann trabaja casi exclusivamente con los testimonios de sobrevivientes de los acontecimientos de la época, víctimas y victimarios directos e indirectos, pero también entrevista a personas que vivían cerca de los campos. Se construye así un archivo de la voz, de la palabra, del testimonio, en una inusual memoria cinematográfica. Dice Derrida sobre el film: «Pues la imagen cinematográfica permite a la cosa misma (un testigo que habló, un día, en un lugar) no ser ya reproducida, sino producida de nuevo «ella-misma ahí». Esta inmediatez del «ello-mismo ahí», pero sin presencia representable, producido en cada visión, es la esencia del cine, así como del film de Lanzmann» (Derrida, «El cine y sus fantasmas»). ${ }^{34}$

31 Lo que causó un escándalo fue el hecho de que a petición del gobierno alemán, el film nominado como propuesta francesa para el festival de Cannes en 1956, fuera realmente retirado de la competencia.

32 En el film hay también una metarreflexión sobre el cine como museo - el «yo he visto» de la mujer-frente al testimonio: «yo lo he vivido», lo cual permite relacionarlo, en este plano, con Shoa. Por otra parte, El año pasado en Marienbad (1961), un trabajo realizado por Resnais junto a Alain Robbe-Grillet, aunque no remite explícitamente a la memoria traumática de la Segunda Guerra Mundial, subvierte las coordenadas espaciotemporales en los recuerdos de sus personajes para constituir un intersticio fílmico que produce y reproduce su propia memoria con imágenes que se repiten, que se varían y que se contradicen entre ellas, también con relación al comentario, igualmente repetitivo y desconcertante. Cfr. los análisis de Deleuze (158-170) sobre el cine de Resnais: éste se desplaza desde una memoria colectiva a una memoria paradójica entre dos o más individuos, para llegar a una «memoria-mundo» (159) de capas de pasado coexistentes en el Pensamiento cartografiado de los «mecanismos cerebrales, mecanismos monstruosos, caóticos o creadores» (169).

33 Cfr. la discusión sobre la imagen y la representación (im)posible y necesaria del Holocausto en DidiHuberman 2004, donde el autor retoma la polémica levantada por Gérard Wajcman respecto de las fotografías expuestas en la muestra «Memoria de los campos» (2001) en París.

34 Germania anno zero (1948), de Roberto Rossellini, es tal vez el film más impactante que muestra y narra por primera vez el desastre que caracteriza la situación de Posguerra en Alemania. Deleuze lo identifica 
En el contexto latinoamericano contemporáneo a Imagen latente destacan algunos films argentinos poco conocidos. Ana Amado, en su libro sobre cine argentino y política, parte, entre varias preguntas más, de la siguiente inquietud: «¿A través de qué selección de imágenes y de narraciones opera la memoria, como práctica individual y/o colectiva, en la construcción de imaginarios estéticos y políticos?» (Amado, 12). Entre su corpus de films producidos entre 1980 y 2007, está El ausente de Rafael Filipelli, del año 1987. ${ }^{35}$ Amado señala que en este film, como también en Un muro de silencio (1992) de Lita Stantic ${ }^{36}$, se encuentran por un lado notables elementos autobiográficos a nivel diegético, y que por otro lado, «el dispositivo fílmico es incorporado materialmente en el interior de sus ficciones y, mostrando el proceso mismo de su construcción, cuestionan de distinta manera los mecanismos representativos de la realidad.» (117). A partir de estas observaciones, se da un llamativo parentesco entre los dos films argentinos e Imagen latente, con la diferencia de que en Argentina, el proceso de la transición democrática llevaría ya unos años, mientras en Chile se produjo el plebiscito sobre el futuro político del país en el año 1988. Los tres ponen en escena la búsqueda de un ausente en imágenes latentes:

al comienzo del segundo tomo de sus Estudios sobre cine con un cambio radical de las imágenes: sería uno de los films que pone en escena la crisis de las relaciones sensoriomotrices que caracterizaban a las imágenes-movimiento. Aguilar subraya este hecho expresado en varias secuencias del film señalando la ruptura entre la «masa y el líder, de los planos generales y los primeros planos, de la voz que habla y el pueblo que asiente, propios del cine de Leni Riefenstahl» (Aguilar, 44). Esa falta del pueblo llevaría a un «nuevo modo de entender las relaciones entre la política y el pueblo en el cine» (44) de la imagen-tiempo (o del «cine moderno») que, según Deleuze, se instala a partir del neorrealismo. No podemos dejar de mencionar, por otra parte, los intentos del propio cine alemán de (re)construir una memoria y una conciencia cinematográfica nueva, en directores como Rainer Werner Fassbinder, Alexander Kluge, Werner Herzog, Wim Wenders.

35 El ausente, meta-film en el que participa Beatriz Sarlo como «directora» de un film sobre un sindicalista secuestrado y desaparecido, prácticamente nunca ha tenido público. Para una retrospectiva en Buenos Aires, en 2004, Filipelli cuenta: «Mi idea de la película era que, desde el comienzo, se supiera todo lo que iba a pasar y, entonces, todo consistía en ver cómo. No me considero un cineasta bressoniano, pero eso lo asocio con el título y el resultado de una de sus películas: Un condenado a muerte se escapa. Es el primer título que pone de manifiesto un final. Ya sabemos que el tipo se escapa, lo único que hay para ver es cómo se escapa. Yo creo que eso es la modernidad. Al mismo tiempo, la modernidad tiene la forma de la tragedia: si algo define a la tragedia es que la suerte está echada desde el comienzo". Agradezco este texto citado en el programa, a David Oubiña, uno de los organizadores de la retrospectiva. Cfr. Martins 2001, uno de los pocos estudios que trabaja sobre este y otros films de la época, entre ellos Un muro de silencio.

36 Un muro de silencio es un trabajo de duelo de estructura compleja y opera con varias estrategias de puesta en abismo: cine en el cine, utilización de material fílmico y fotográfico de archivo, desdoblamiento de las formas representacionales, entrelazamiento de distintas capas espaciotemporales. Stantic ficcionaliza su propia experiencia y convivencia con Pablo Szir, militante de izquierda, desaparecido en 1976, sin mencionarlo explícitamente. Szir era pareja de la directora y había fundado, junto a Raymundo Gleyzer, el "Cine de la Base» (un dato interesante en nuestro contexto: Szir estuvo detenido junto a los padres de Albertina Carri). Stantic, después de producir varios films de María Luisa Bemberg, se perfila en los noventa como figura promotora y productora del nuevo cine argentino. Su primer largometraje se opone claramente a La historia oficial (1985) de Luis Puenzo, que había apuntado, en clave melodramática, a la toma de conciencia y de conocimiento a posteriori de la clase media argentina sobre los hechos ocurridos en el país durante la dictadura, convirtiéndose, finalmente, en el cine oficial de la transición (ganadora del Óscar en 1985) y, por ende, en «historia oficial». El film de Stantic abre con un travelling en un terreno con edificios abandonados, un antiguo centro de detención, por los que caminan la directora inglesa y el guionista del proyecto del film dentro del film, y mediante una voice over femenina con acento inglés (Vanessa Redgrave, la «directora» del film), el primer enunciado deja las cosas en claro: «La gente sabía lo que estaba pasando por aquí.» Y la respuesta del guionista: "Y los que no sabían, sospechaban». Casi las mismas palabras, en el mismo lugar siniestro, concluyen el film, solo que esta vez las enuncian la protagonista de la historia que se filma dentro del film, junto a su hija (en el plano «real», Stantic tenía una hija con Szir). 
ausencia y latencia, conceptos que figuran en dos de los títulos, van de la mano y son parte de la estética espectral de los films. Cito un pasaje de Derrida, pertinente en este contexto, que apunta al estatus de la imagen cinematográfica y dialoga con los análisis de Amado: «la imagen en tanto que imagen, es trabajada materialmente por la invisibilidad. No forzosamente la invisibilidad sonora de las palabras, sino otra distinta, y creo que el anacoluto, la elipsis, la interrupción, forman quizás aquello que el film guarda en sí. Lo que se ve en el film tiene sin duda menos importancia que lo no-dicho, lo invisible que es lanzado como un tiro de dados, relevado o no (esto es asunto del destinatario) por otros textos, otros films» (Derrida, «El cine y sus fantasmas»).

Amado, a su vez, señala que es precisamente la paradójica condición de sobrevivientes que motiva hacer los films: «... la culpa y la desazón en los narradores/biógrafos de $E l$ ausente, actualizan la cuestión de la supervivencia como nudo trágico. [...] El intelectual de El ausente vuelve una y otra vez la mirada sobre la última fotografía del sindicalista desaparecido y de otros colegas muertos [...], preguntándose ‘por qué no estoy ahí??» (Amado, 119). Sobre la estructura fantasmal de la inmerecida supervivencia, expuesta en el cine, dice Derrida: «El cine es el simulacro absoluto de la supervivencia absoluta. Nos relata aquello desde donde no se vuelve, nos relata la muerte. Por su propio milagro espectral nos muestra aquello que no debería dejar rastros. Es entonces dos veces rastro: rastro del testimonio mismo, rastro del olvido, rastro de la muerte absoluta, rastro del sin-rastro, rastro del exterminio» (Derrida, «El cine y sus fantasmas»). La «desconfianza en la visión para construir una 〈historia de ausentes»» (Amado, 124) que Amado detecta en los films argentinos, está muy presente también en Imagen latente. Y cito una vez más un pasaje del libro de Amado que suena como si hubiera escrito también sobre el film de Perelman: «Los personajes de estas películas buscan explicaciones, pretenden encontrar un discurso de verdad para impedir que el pasado se degrade en puro recuerdo, dentro de ficciones que, a su vez, interrogan (al cine, a las imágenes) sobre los modos de interpelarlo» (125).

Durante los créditos del film de Perelman ${ }^{37}$ vemos fotografías de la lucha política, a las que se suman voces de reclamos del pueblo por los desaparecidos y víctimas durante la dictadura. Con esto, estamos viendo la representación de un momento histórico que coincide con la época de la producción del film. ${ }^{38}$ Después vemos escenas de las marchas callejeras en favor de Allende en 1973, pocos meses antes del golpe, imágenes nebulosas,

37 Perelman destaca por una filmografía densa e inconstante a lo largo de casi cuarenta años: filmó a principios de los setenta en proyectos de documentales políticos, hizo A la sombra del sol (1974), junto al codirector Silvio Caiozzi y al camarógrafo Jorge Müller, quien había colaborado en La batalla de Chile de Patricio Guzmán, y que fue secuestrado y desaparecido poco después del estreno de A la sombra del sol, que fue el primer largometraje chileno realizado durante la dictadura. Después de Imagen latente, Perelman vuelve al cine con Archipiélago (1992), film complejo que, junto a La frontera (1992) de Ricardo Larraín, inaugura un difícil discurso "postdictatorial» en el cine chileno de ficción. El film opera en varias capas espaciotemporales cuyos puntos de fuga son acontecimientos violentos durante la dictadura pinochetista, y otros en una isla del sur de Chile (territorio elegido también por Larraín). El film trabaja, además, con imágenes de archivo, filmadas por el sacerdote salesiano Alberto Agostini entre 1915 y 1928 en la Patagonia chilena. En 2009, Perelman empieza a filmar su cuarto largometraje, La lección de pintura, inspirado en el cuento del mismo título de Adolfo Couve, pero trasladado a la época de la dictadura.

38 Escribe Nelly Richard en Residuos y metáforas: «Donde se conjuga más dramáticamente la memoria del pasado es en la doble narración cruzada de los detenidos-desaparecidos y de sus familiares que luchan contra la desaparición del cuerpo, debiendo producir incesantemente la aparición social del recuerdo de su desaparición [...] frente a la ausencia del cuerpo, deben prolongar la memoria de su imagen para mantener vivo el recuerdo del ausente y no hacerlo «desaparecer» una segunda vez mediante el olvido» (42). 
a veces tambaleantes y distorsionadas en su materialidad, acompañadas por el ruido de un proyector. La factura de estas imágenes lleva a pensar en documentos históricos, mal conservados, y remite a su procedencia de un archivo que contrasta con el material fílmico usado por Perelman para hacer Imagen latente. De hecho, estas imágenes fueron filmadas por el mismo Perelman en 1973, un material que no pudo llevar al exilio. Al volver a Chile varios años más tarde, encontró por casualidad el rollo en el viejo laboratorio donde había trabajado. De ahí, la decisión de utilizar el material para el nuevo film. Algunos instantes más tarde, vemos por primera vez a Pedro, ahora en el tiempo diegético del film, situado en 1983, un fotógrafo que proyecta y mira estas imágenes que vemos nosotros, en una habitación de su casa (en la banda de sonido escuchamos en primer plano una música que se convertirá en la banda sonora del film, y en el trasfondo hablan una mujer y un niño). ${ }^{39}$ Se escucha, en forma de voice over, la voz (interior) de Pedro que dice: «Por Dios, qué bonito", y después de un tiempo: «Hay que cuidar los recuerdos, que no se los ensucien a uno. Pelear por ellos. ¿No teníamos pasado en esa época?» (Perelman, Imagen Latente). A través de estos enunciados, el personaje expresa su deseo de rescatar y reconstruir con las imágenes su propio pasado, suprimido y borrado por la violencia del régimen dictatorial. Se trata de una memoria perdida y latente en archivos personales de textos e imágenes.

Luego de mostrar el título del film en letras rojas sobre fondo negro, hay un cambio de escenario. Vemos primero un negativo iluminado, y después a la mujer de Pedro, también fotógrafa, en su laboratorio. Lleva a cabo las típicas operaciones de su oficio: toma medidas del papel, corta negativos y revela algunas fotos en blanco y negro. Entremedio, el film salta de nuevo a las imágenes históricas de 1973 y se escucha una vez más la voz, comentando las escenas: «El presente es de lucha y el futuro es nuestro». Un enunciado que remite a la lucha política en la época de la Unidad Popular, todavía vigente en ese momento, y unos momentos después se escucha: «El presente es una mierda». Y como auto-respuesta a esta frase que expresa la resignación ante el fallido proyecto de la «vía chilena al socialismo», convertido en utopía destruida, dice la voz: «El futuro es pasado visto en el espejo del presente, ¿me explico? El presente es un espejo». Esta condición del presente entre pasado y futuro es espectral, tan espectral como la voz que, en un fade out del sonido, sigue divagando sobre la calidad del presente como espejo entre el pasado y el futuro, mientras volvemos a ver el trabajo con las fotos que realiza la fotógrafa en su laboratorio casero. Finalmente, y antes de que comience la narración propiamente diegética, un intertítulo en letras rojas, firmado por P.P., dice que éste filmó fotografías y documentos conservados por la familia Perelman. ${ }^{40}$ Estas imágenes del archivo personal son utilizadas en varias ocasiones para la construcción diegética del film. Se verán, durante la historia de búsqueda que se cuenta en Imagen latente, fragmentos de películas caseras y fotografías del hermano de Pedro, desaparecido en 1975 por el régimen autoritario en Villa Grimaldi.

39 Hay cierto símil entre el personaje del fotógrafo Pedro y la figura del cineasta en Restos: los dos proyectan y observan las imágenes difusas del archivo, que en Imagen latente adquirirán, no obstante, un valor personal.

40 P.P. no son necesariamente las iniciales del director, al menos las compartiría con su «alter ego» fílmico, Pedro. Hay un juego de nombres en el film que remite a una ficcionalización fracturada, un cruce entre documental y ficción que caracteriza sobre todo las primeras secuencias, pero que también atraviesa la diégesis en otros momentos. 
Las secuencias iniciales del film ponen en escena el proceso de memoria fotográfica y cinematográfica en su materialidad con el fin de crear una memoria colectiva. ${ }^{41} \mathrm{La}$ proyección de las imágenes de 1973 provoca en Pedro una gran inquietud y lo lleva a la búsqueda de su hermano y la imposible reconstrucción de su historia, análoga a miles de otras víctimas cuyo destino ha quedado en la incertidumbre. Emprende esta búsqueda, que también es una búsqueda de sí mismo y de una explicación sobre su condición de sobreviviente, a través de testimonios de compañeros de ruta del hermano, visitas de lugares por los que había transitado el hermano, y aproximaciones peligrosas al mismo sitio donde habían ocurrido las torturas. En una escena, Pedro saca fotos de la Villa Grimaldi, la antigua casona de José Arrieta en Peñalolén, transformada en un centro clandestino de detención, donde las huellas de su hermano se pierden irrecuperablemente, y Pedro toma fotos como si fuera posible revertir el tiempo o encontrar el origen y la trama del crimen a través del proceso fotográfico. ${ }^{42}$

Más allá de la puesta en escena de la recuperación del hermano a través de estrategias topográficas y fotográficas en una suerte de mnemotecnia fantasmagórica y abis$\mathrm{mal}^{43}$ - que en varios momentos parece prefigurar las paradojas cinematográficas de Los rubios (2003), de Albertina Carri- el trabajo realizado por la mujer de Pedro, sus cortes y revelados que son visibilizados al principio del film, remiten a la intervención y la manipulación de la materia fotográfica misma, ya que la foto es producto de un proceso químico. ${ }^{44}$ La idea de una imagen escondida, potencial, invisible y archivada en una sustancia reveladora en el nivel fotoquímico cuyo proceso observamos en el film, es analogizable a los procesos de memoria tal como los entienden Freud y Derrida ${ }^{45}$ : las

41 Cabe mencionar en este contexto el documental La ciudad de los fotógrafos (2006) de Sebastián Moreno sobre los integrantes de la Asociación de fotógrafos independientes (Afi), varios de ellos víctimas del régimen, que durante la dictadura documentaron un gran número de hechos ocurridos y, con eso, crearon un archivo importante de fotografías.

42 Aquí, como en Blow up (1966) de Michelangelo Antonioni, la fotografía es una operación engañosa de revelación y descubrimiento de la verdad en un proceso de llevar lo invisible a la visibilidad, lo latente a lo manifiesto, y durante el que se dan abismos de la evidencia entre alucinación, (re)construcción, imaginación y proyección, en un espacio indeciso entre fotografía y cinematografía (y literatura, si queremos tomar en cuenta Las babas del diablo (1959), cuento de Julio Cortázar en el que se inspiró Antonioni). Pedro, al contrario de Thomas en Blow up, finalmente no hace nada con estas fotos. Inmediatamente después de tomarlas, saca y tira el rollo ante la amenaza de ser descubierto por agentes del régimen que lo han perseguido en un taxi.

43 Se trata de estrategias de una memoria tópica e imaginaria que, desde Simónides de Ceos, Platón y Aristóteles, forman parte de una larga historia de la mnemotecnia, entendida como uno de los cinco elementos de la retórica en las obras de Cicerón y Quintiliano. La más importante fuente conservada sobre el arte de la memoria que se basa en la impresión mental de lugares e imágenes es, según el libro canónico de Frances Yates, el anónimo Ad Herennium (primer siglo a.C.). La fotografía como técnica de reproducción masiva y desde su estatus ontológico de ser una «huella digital» (André Bazin) y un "haber-estado-ahí» (Roland Barthes) de las cosas reproducidas, significa, entre muchas otras cosas, un salto cualitativo respecto de las mnemotecnias modernas, porque genera fenómenos de inestabilidad y desconcierto en la configuración de memorias culturales, individuales y colectivas, que culminaron con el cine como «arte del presente» (Daney).

44 Dice la definición científica: «Para obtener una imagen fotográfica, es preciso exponer una emulsión sensible a la luz. Se produce en el seno de esta emulsión una modificación invisible, pero sin embargo real, que lleva el nombre de imagen latente. Se denomina así, porque contiene en potencia una imagen visible. Esta aparece cuando se hace actuar sobre la imagen latente, una sustancia denominada revelador, en la operación del revelado» (http://www.textoscientificos.com/fotografia/latente).

45 Derrida piensa y escribe constantemente sobre los conceptos de Freud, pero en «Freud y la escena de la escritura» (1967) hace dialogar su propia idea de la escritura como huella, suplemento y différance con el concepto del «abrirse-paso» (Bahnung), desarrollado en la "Nota sobre el bloc mágico" (1925), donde Freud metaforiza el funcionamiento y la estructura del aparato síquico y de la memoria con la ayuda de 
imágenes latentes, borradas, invisibilizadas, reactualizadas en potencia que caracterizan las operaciones de la memoria espectral entre recuerdo y olvido. En todo caso, el cine, productor de imágenes latentes desde los archivos, se transforma en agente insoslayable de la construcción de la memoria cultural. Las imágenes-tiempo del comienzo de Imagen latente juegan con las estructuras sonópticas que configuran la imagen y se mueven entre el tiempo cinematográfico de un presente siempre espectral, y las huellas fotográficas del pasado. Pedro, el fotógrafo, revela las imágenes y repite los pasos de un sujeto muerto, sin voz, que es su hermano, en un viaje fantasmal durante el que reanima las imágenes latentes y reveladas, generadas por el proceso fotográfico y fílmico, en busca de la imagen justa del pasado y del futuro en el espejo del presente. ${ }^{46}$ Lo que surge al final del film, sin embargo, es un espejo trizado, cuyo reflejo se ha opacado. Pedro, después de pasar por varias vicisitudes a lo largo de su búsqueda, viaja en su auto por un Santiago lluvioso. De repente se escucha su voz: «Porque el futuro es un reflejo del pasado. Por eso que nunca es tan distinto. La gente es la misma» (Perelman, Imagen Latente).

El film, impregnado por un gesto desolador que refleja el momento histórico en el que fue producido, realiza un cuestionamiento de la imagen «verdadera» que busca, por ejemplo, el cine de Patricio Guzmán. En este sentido, las estrategias de Perelman en Imagen latente y también en Archipiélago, se inscriben en y continúan un cine crítico, distanciado de un Modo de Representación Institucionalizado (Burch), sea este implementado por la derecha o por la izquierda, y que practicaban realizadores como Raúl Ruiz y Pablo de la Barra alrededor de $1970 .{ }^{47}$ De todas maneras, Perelman dedica su film a los «Familiares de los Detenidos Desaparecidos que nunca dejarán de encontrarlos». El presente, finalmente, es un estado latente entre las imágenes del pasado y las del futuro. Verdad y mentira son categorías que en estas circunstancias no resultan apropiadas y convincentes, mientras la categoría de la imagen justa, con todas sus ambigüedades y espectralidades, sí lo es. El film de Perelman es un impactante archivo de imágenes en su movimiento agónico, desesperado, necesario y paradójico de la memoria y de la justicia, un archivo que oscila entre la imagen latente y la imagen justa.

esa «máquina mágica» de escribir. Cito un pasaje clave de este texto, que también implica una revisión de la noción de archivo, realizada casi treinta años después en Mal de archivo (1995): «El texto no se puede pensar en la forma, originaria o modificada, de la presencia. El texto inconsciente está ya tejido con huellas puras, con diferencias en las que se juntan el sentido y la fuerza, texto en ninguna parte presente, constituido por archivos que son ya desde siempre transcripciones (Derrida, 291).

46 Nuestro trabajo enfoca las relaciones entre el archivo, le memoria y el cine, y no se centra en la relación entre el sujeto-creador y su escritura, por medio de la cual el sujeto realiza un trabajo autorreflexivo y performativo de memoria y de duelo, en un entramado complejo de representaciones performáticas del trauma histórico. Estos aspectos son tratados, basándose en los trabajos de Dominick LaCapra y Diana Taylor, entre otros, por Milena Grass, en su tesis para obtener el grado de Magíster en Estudios latinoamericanos de la Universidad de Chile (2010), titulado «Imagen Latente y Los Rubios: Performatividad Cinematográfica y Estética de la Memoria en el Cine Latinoamericano». Por otra parte, cabe mencionar también, a nivel narrativo y sonoro del film, los elementos melodramáticos de la trama en la cual se desarrolla la historia de la búsqueda realizada por Pedro, recurrentes en otros films de la misma temática (como La historia oficial).

47 Cfr. en este contexto el trabajo de Iván Pinto y Luis Horta, «Vías no realizadas en el cine político chileno. Parodia, extrañamiento y reflexividad», en el Dossier "Cine chileno y política», Aisthesis No 47, 2010. 


\section{ECOS (OTROS RESTOS)}

El palacio de la risa (1995): la búsqueda de las imágenes justas nos lleva de nuevo al escritor Germán Marín. ${ }^{48}$ Su novela corta amplía de forma bizarra el archivo de las imágenes latentes del film de Perelman. El «Palacio de la Risa» es el nombre cínico que los militares y torturadores le dieron a la Villa Grimaldi cuando la transformaron en centro de detención en 1973. El sujeto-narrador del texto es un exiliado retornado a principios de los 90 que visita el terreno devastado de la propiedad, una mañana de diciembre, en busca de dilucidar un enigma. El gobierno militar se había apresurado en borrar las huellas del centro y dinamitó las edificaciones; en 1987 vendió la finca a una empresa constructora, propiedad de un familiar del militar a cargo de la CNI (ex-DINA). Ese «borrar el pasado» (97), como dice el narrador al comienzo, es una característica del país al que volvió y en donde «no se deseaba sacar a la luz por completo los oscuros y graves episodios sucedidos» (98). Estamos frente al mismo objetivo que encontramos al comienzo del film de Perelman: aquí es la escritura que llevaría el material latente del archivo a la superficie. Desde el lugar imaginario en ruinas, sentado al pleno sol, en la orilla de una fuente de piedra junto a la piscina - dos obras que sobrevivieron el derrumbe- el narrador inicia su viaje mental de recuerdos sobre el lugar en el que se encuentra. ${ }^{49}$

En la compleja construcción temporal de la novela se pueden identificar varias capas temporales que se superponen en el relato. La infancia del protagonista transcurre en la casona aristocrática donde vivía su amigo Antonio, al que visitaba con frecuencia. Se trata de una época idílica, llena de recuerdos agradables, asociada al patrimonio artístico e intelectual que albergaba la casa de la familia Arrieta. La segunda capa se sitúa en la época de la Unidad Popular que comparte con su amante Mónica, que lo acompaña, en una noche de 1971, en su regreso a la casona, convertida en una discoteca llamada Paraíso, destinada a una juventud adinerada y antimarxista (este paraíso, descrito con algún espanto premonitorio, termina en el infierno unos años más tarde). Otra capa temporal es el exilio del narrador en Barcelona a partir de 1973, durante el que pierde de vista a Mónica y empieza a averiguar sobre ella. De forma paralela, transcurren las torturas en Villa Grimaldi durante la dictadura en Chile. El retorno es posterior a 1990 y la recapitulación de recuerdos en las ruinas pertenece a otra capa temporal. Y, finalmente, en un presente de la narración, es posible la realización de una especie de segundo recuento de forma ordenada y coherente. Marín despliega, en este sentido, una memoria escritural en varios estratos que oscila entre lo personal y lo colectivo, tal como lo hará Lazos de familia, cinco años más tarde, dialogando con imágenes-objeto de diversa índole.

Aquí, el narrador cuenta una prehistoria de la casa y la reviste, con sus vivencias y experiencias en el lugar, de una memoria otra que la traumática antes de que se convirtiera en una topografía del terror. ${ }^{50}$ Pero mientras avanza el relato, Mónica se revela como elemento clave que da sentido a la nueva visita del narrador a esta casa: «En diversos instan-

48 Jean-Louis Comolli, en un taller que dictó en la Alianza francesa de Buenos Aires, entre el 18 y 19 de octubre de 2010, señaló que los espectros de la literatura son invisibles, mientras que los del cine son visibles.

49 El tono de la narración recuerda en algunos pasajes la escritura de W.G. Sebald, escritor alemán que en varios de sus libros, escritos durante los años noventa y llenos de imágenes-objetos de índole diversa (dibujos, fotografías, stills fílmicos, recortes de prensa, boletas, notas escritas a mano) que dialogan con los textos, pone en escena los relatos de narradores durante sus viajes y visitas a lugares siniestros y desolados, en ruinas.

50 Cfr. el análisis del texto en Lazzara 2007. 
tes del exilio, bajo una oscura confusión llena de imágenes, había pensado en el momento de ese reencuentro, en que la nostalgia que a veces me sobrevenía, al recordar las visitas cuando niño al lugar, era barrida por el espanto de tener conciencia de lo que allí había sucedido. Desde luego, al imaginar aquel día lejano, que ahora era el presente que fluía, se me aparecía también Mónica» (Marín, 175). El motivo de esta vuelta a Peñalolén es finalmente la búsqueda de ella, personaje enigmático y, según algunos testimonios consultados por el narrador y documentos encontrados en diversos archivos, colaboradora del régimen en esa misma Villa Grimaldi, después de haber sido torturada en otro centro de detención. Sobre todo María del Carmen Posada, una mujer que había pasado por la misma experiencia que Mónica, con la que el narrador mantiene una relación de curiosa amistad, le confirma lo sospechado. ${ }^{51}$ Pero esta resolución del enigma que moviliza la trama de la novela, además de ser mencionada en varias ocasiones por el mismo narrador, se da en base a un testimonio incompleto, inconsistente por un personaje frágil, culpable, alcohólico y poco creíble: «María del Carmen era en gran parte una ficción de su propia vida» (191). No es difícil ver en esto un cuestionamiento del discurso del sobreviviente y concluir que lo que dice se basa esencialmente en emocionalidades y rumores. Por otra parte, la obsesión del narrador por entender qué pasó con Mónica en Villa Grimaldi puede traducirse también en una búsqueda del narrador por entender un destino que perfectamente, bajo otras circunstancias, pudo haber sido el suyo: la tortura, la desaparición o la colaboración. De tal forma, se podría hablar de una purgación o reparación que se extiende desde un sujeto que realiza un trabajo de duelo en un espacio que, por su parte, evidencia un trauma reciente y profundo al encontrarse completamente devastado y despojado del esplendor que hacía tiempo poseía. El texto despliega en su conjunto, manifestando gestos escépticos y melancólicos, la inevitabilidad de las coincidencias y figuraciones del terror que marca el presente como espejo del pasado y del futuro. Como en Imagen latente, y ahora en tiempos postdictatoriales, se trata de un espejo trizado:

Qué cantidades de errores justos provoca la nostalgia. Jamás pude imaginar en el extranjero que algún día regresaría al lugar donde antes se levantaba el parque y que, en su reemplazo, encontraría el vacío de un terreno desolado cubierto de cardos. Al observar las malezas que brotaban entre los escombros, comprendí esa mañana de pleno verano que había ocurrido una profunda desgracia entre esos murallones de adobe, intactos aún, como si quisieran ocultar, llenos de vergüenza, el secreto de lo sucedido en el interior. De mi parte, debo admitir, me sentía un poco culpable de estar vivo [...] Me asediaba en la casa, embriagado por mis invenciones, la sombra de la presencia de Mónica, pues en los sueños todas las edades se convierten en una, como dice James Joyce [...] Me pregunté mientras recorría aquello con la mirada a qué país había llegado hacía tres meses, pues, aunque lo deseara, éste ya no parecía ser el mío luego de pasar por la verdad de esa mañana (Marín, 129-130).

Los rubios (2003): Desde su aparición, el film de Carri ha generado una abundante crítica. ${ }^{52}$ Significa un quiebre fulminante en la estética del cine hecho por los hijos de los

51 Las experiencias de María del Carmen y Mónica se reflejan también en los textos publicados por Luz Arce y Marcia Merino en 1993 y 1994, respectivamente, y que Nelly Richard analiza en un capítulo de Residuos y metáforas. Se trata de dos militantes de izquierda, detenidas y torturadas por la DINA, y delatoras-colaboradoras del régimen durante diez años, convertidas al catolicismo antes de publicar sus testimonios (cfr. Richard, 51-73).

52 El film - que sigue siendo el más radical y desconcertante en una serie de films sobre el tema de los desaparecidos durante la dictadura militar en Argentina, realizados en los últimos diez años, entre ellos Garage Olimpo (Bechis, 1999), Figlio/Hijos (Bechis, 2002), Kamchatka (Piñeyro, 2002), Papá Iván (Ro- 
desaparecidos sobre la desaparición de sus padres, y demuestra por qué, en el sentido de Rancière, estética y política son inseparables y dividen a través de obras artísticas disensuales el orden de lo sensible. La película de Carri es abismal en muchos niveles y sentidos, es un emocionante testimonio sobre las paradojas de la representación mediatizada de la desaparición, «un doloroso cuestionamiento de la naturaleza de los recuerdos» que «pone en escena la imposibilidad de reconstruir lo irreparable» (Noriega, 17 y 19). Algunas de sus estrategias de puesta en abismo entre un polo ficcional y otro documental son el desdoblamiento del personaje central en actriz, directora e hija de padres desaparecidos; la no inclusión de fotografías en edad adulta de sus padres; la aparente desconsideración de las entrevistas testimoniales de los compañeros militantes de sus padres como fuente histórica de la verdad; la inserción de las entrevistas con los antiguos vecinos de Ana María Caruso y Roberto Carri que producen efectos siniestros precisamente por su «sinceridad» delatora y su revelación inventada de lo ocurrido — de allí también el título del film-; la inserción de carteles de relieve que nombran los sucesos históricos o citan pensamientos de Carri; los stop motion con los Playmobils que «juegan» o imitan varias escenas de la vida de la joven Albertina y el secuestro de sus padres; la discusión del equipo de filmación sobre el fax recibido del INCAA que pide modificar el guion de la película para financiarla; las pelucas que en su «falsedad» representan una nueva identidad, siempre precaria: las pelucas que todos los integrantes del equipo tienen puestas al final del film cuando caminan por el campo - con la música de Charly García en la banda sonora- pueden significar que «los padres de Albertina Carri, inalcanzables, distantes, son reemplazados metafóricamente por la familia que se formó al calor del trabajo en las jornadas de filmación» (Noriega, 44). La filiación sanguínea de la familia natural es reemplazada por una afiliación irónica de pelucas rubias, la nueva familia cinematográfica. ${ }^{53}$ Gonzalo Aguilar, en su análisis de varios films de los hijos de desaparecidos que ejercen un trabajo de duelo en y con el cine, señala que Carri es la única que logra salir de ese duelo, porque Los rubios, con su frivolidad irónica, muestra precisamente el fracaso de la representación del duelo, tanto visual como oral-auditiva, de forma irreverente e incondicional. El film se mueve entre ausencias y latencias en las mediaciones que intenten transmitir sensaciones puras, y al mismo tiempo transmite estas mismas sensaciones de dolor, frustración y desesperación, en un cine espectral: «Frente a la apuesta por la militancia política de sus padres, Albertina Carri responde con una apuesta por la estética, como el territorio en el que vale la pena vivir o dar la vida» (Aguilar, Otros Mundos, 180).

Los rubios, que pone en escena la insostenible e injusta ausencia de los desaparecidos y la imposibilidad de hablar — correctamente- de esa obsesión espectral de re-presen-

qué, 2004), Nietos. Identidad y memoria (Ávila, 2004), Cautiva (Biraben, 2005), Crónica de una fuga (Caetano, 2006), M (Prividera, 2007) — ha ganado varios premios y ha provocado innumerables y polémicas intervenciones en los medios. La crítica más tajante y minuciosa es de Kohan 2004, a la cual reaccionaron, entre otros, Aguilar 2006 y Noriega 2009. Es llamativo, en nuestro contexto, que también se lo haya relacionado con las estrategias iconofóbicas de Lanzmann.

53 En $M$ (2007), Nicolás Prividera da una respuesta fílmica y política a Los rubios al aplicar estrategias considerablemente distintas: durante su investigación sobre su madre desaparecida en el Instituto Nacional de Tecnología Agropecuaria (INTA), aplica un intransigente método de interrogación a amigos, colegas y otros testigos (comparable, con reservas, al método de Lanzmann); filma con una estética deliberadamente "coja» en la construcción de las imágenes que contrasta con otras imágenes "puestas en escena»; muestra constantemente fotos y fragmentos de films donde aparece su madre hasta que en una secuencia, su sombra se proyecta sobre estas imágenes; y transfiere su trabajo individual de memoria, duelo y búsqueda a un plano colectivo, histórico. Cfr. las observaciones sobre los dos films realizadas por Noriega: http://www.elamante.com/index.php?option=content\&task=view\&id=1254. 
tarlos, le permitirá a Carri hacer otro cine: Géminis (2005) y La rabia (2008) exponen, en su máxima crudeza, las violencias y transgresiones de diferentes entramados sociales e históricos (el incesto, la locura, la violación, el parricidio), relacionados entre ellos por finos y crueles vasos comunicantes. ${ }^{54}$ Estas otras figuras, tan radicales como las de Los rubios, de igual manera abren y amplían un archivo cinematográfico que sustenta aquel proceso estético-político de redistribución de las relaciones entre los cuerpos, las imágenes, los espacios y los tiempos.

\section{REFERENCIAS}

Agamben, Giorgio. Lo que queda de Auschwitz. El archivo y el testigo. Homo sacer III. Valencia: Pre-textos, 2005. Medio impreso.

Aguilar, Gonzalo. Otros mundos. Un ensayo sobre el nuevo cine argentino. Buenos Aires: Santiago Arcos, 2006. Medio impreso.

—. "Gilles Deleuze o la armonía del cine». Kilómetro 111. Ensayos sobre cine 7 (2008) 37-54. Medio impreso.

Amado, Ana. La imagen justa. Cine argentino y política (1980-2007). Buenos Aires: Colihue, 2009. Medio impreso.

Barthes, Roland. Lo obvio y lo obtuso. Imágenes, gestos, voces. Barcelona: Paidós, 1986. Medio impreso.

-. La Cámara lúcida. Notas sobre la fotografía. Buenos Aires: Paidós, 2003. Medio impreso.

Baudry, Jean-Louis. «The Apparatus. Metapsychological Approaches to the Impression of Reality in Cinema». Narrative, Apparatus, Ideology. A Film Theory Reader. Ed. Philip Rosen. New York: Columbia University Press, 1986. 299-318. Medio impreso.

Bazin, André. ¿Qué es el cine? Madrid: Rialp, 2006. Medio impreso.

Bonitzer, Pascal. El campo ciego. Ensayos sobre el realismo en el cine. Buenos Aires: Santiago Arcos, 2007. Medio impreso.

Burch, Noël. El tragaluz del infinito (Contribución a la genealogía del lenguaje cinematográfico). Madrid: Cátedra, 2006. Medio impreso.

Carri, Albertina. Los rubios, Cartografía de una película. Buenos Aires: Bafici, 2007. Medio impreso.

Cavallo, Ascanio y Carolina Díaz. Explotados y benditos. Mito y desmitificación del cine chileno de los 60. Santiago: Uqbar, 2007. Medio impreso.

Cavallo, Ascanio; Douzet, Pablo y Cecilia Rodríguez. Huérfanos y perdidos. Relectura del cine chileno de la transición 1990-1999. Santiago: Uqbar, 2007. Medio impreso.

Cherchi Usai, Paolo. La muerte del cine. Historia y memoria cultural en el medioevo digital. Barcelona: Laertes, 2005. Medio impreso.

Corro, Pablo; Larraín, Carolina; Alberdi, Maite y Camila Van Diest. Teorías del cine documental chileno, 1957-1973. Santiago: Instituto de Estética, UC., 2007. Medio impreso.

Da Costa, Cláudio. Cinema Brasileiro (anos 60-70). Dissimetria, oscilação e simulacro. Rio de Janerio: 7Letras, 2000. Medio impreso.

$\overline{54 \quad \text { Cfr. Modarelli } 2009 .}$ 
Daney, Serge. Cine, arte del presente. Buenos Aires: Santiago Arcos, 2004. Medio impreso. Deleuze, Gilles. La imagen-tiempo. Estudios sobre cine 2, Buenos Aires: Paidós, 2005. Medio impreso.

Déotte, Jean-Louis. Catástrofe y olvido. Las ruinas, Europa, el Museo. Santiago: Cuarto Propio, 1998. Medio impreso.

Derrida, Jacques. La escritura y la diferencia. Barcelona: Anthropos, 1989. Medio impreso.

-. Los espectros de Marx. El trabajo de la deuda, el trabajo del duelo y la Nueva Internacional. España: Trotta, 1998. Medio impreso.

-. Mal de archivo. Una impresión freudiana. Madrid: Trotta, 1997. Medio impreso.

- y Bernard Stiegler. Ecografías de la televisión. Entrevistas filmadas. Buenos Aires: Eudeba, 1998. Medio impreso.

—. "El cine y sus fantasmas», (entrevista con Antoine de Baecque y Thierry Jousse). Cahiers du cinéma 556 (2001). Trad. de Fernando La Valle. Sitio Web. Fecha de ingreso: 20 de Octubre de 2010 .

Didi-Huberman, Georges. Imágenes pese a todo. Memoria visual del Holocausto. Barcelona: Paidós, 2004. Medio impreso.

- La imagen superviviente: Historia del arte y tiempo de los fantasmas según Aby Warburg. Madrid: Abada, 2009. Medio impreso.

El Amante. Filipelli, Rafael, dir. Act. Omar Rezk, Roberto Suter, Ana María Mazza. Color. 1989. Medio Fílmico.

Ernst, Wolfgang. Das Rumoren der Archive (El ruido de los archivos). Berlín: Merve, 2002. Medio impreso.

Flusser, Vilém. Los gestos. Fenomenología y comunicación. Madrid: Herder, 1994. Medio impreso.

Friedlander, Saúl (comp.). En torno a los límites de la representación. El nazismo y la solución final. Buenos Aires: Universidad Nacional de Quilmes, 2007. Medio impreso.

González Echevarría, Roberto. Myth and archive. A theory of Latin American narrative. Durham/London: Duke University Press, 1998. Medio impreso.

Grass, Milena. «Imagen Latente $y$ Los Rubios: Performatividad Cinematográfica y Estética de la Memoria en el Cine Latinoamericano». Tesis de Magíster en Estudios Latinoamericanos. Santiago: Universidad de Chile, 2010. Medio impreso.

Hiroshima mi Amor. Resnais, Alain, dir. Act. Emmanuelle Riva, Eiji Okada, Bernard Fresson. AVI. B/N. 1959. Medio Fílmico.

Imagen Latente. Perelman, Pablo, dir. Act. Bastián Bodenhofer, Gloria Munchmayer, María Izquierdo. Color. Macondo, 1988. Medio fílmico.

Internacional. Madrid: Trotta, 1998. Medio impreso.

Kohan, Martín. «La apariencia celebrada». Punto de Vista 78 (2004). Medio impreso.

Kracauer, Siegfried. De Caligari a Hitler. Una historia psicológica del cine alemán. Barcelona: Paidós, 1985. Medio impreso.

La Ferla, Jorge. Cine (y) digital. Aproximaciones a posibles convergencias entre el cinematógrafo y la computadora. Buenos Aires: Manantial, 2009. Medio impreso.

Lazzara, Michael. Prismas de la memoria: narración y trauma en la transición chilena. Santiago: Cuarto Propio, 2007. Medio impreso.

Link, Daniel. Fantasmas. Imaginación y sociedad. Buenos Aires: Eterna Cadencia, 2009. Medio impreso.

Los Rubios. Carri, Albertina, dir. Act. Analía Couceyro. 35 mm. B/N y Color. 2003. Medio Fílmico. 
Manovich, Lev. El lenguaje de los nuevos medios de comunicación. La imagen en la era digital. Buenos Aires: Paidós, 2006. Medio impreso.

Marín, Germán. El palacio de la risa. Santiago: Planeta, 1995. Medio impreso.

-. Lazos de familia. Relatos con imágenes. Santiago: Sudamericana, 2001. Medio impreso.

Martins, Laura. "Cine argentino de los noventa: memoria y/o mercado (sobre Piñeyro, Stantic y Filippelli)». E.I.A.L. 12/2 (Estudios Interdisciplinarios de América Latina y el Caribe) (2001). Julio-diciembre. Medio impreso.

Metz, Christian. El significante imaginario: psicoanálisis y cine. Barcelona: Paidós, 2001. Medio impreso.

Modarelli, Alejandro. «Lo que La rabia nos obliga a ver». Kilómetro 111. Ensayos sobre cine 8 (2009). 172-183. Medio impreso.

Morin, Edgar. El cine o el hombre imaginario. Barcelona: Paidós, 2001. Medio impreso.

Mouesca, Jacqueline y Carlos Orellana. Breve historia del cine chileno. Santiago: LOM, 2010. Medio impreso.

Nancy, Jean-Luc. La representación prohibida. Buenos Aires: Amorrortu, 2006. Medio impreso.

Noche y Niebla. Resnais, Alain, dir. Act. Michel Bouquet, Reinhard Heydrich, Adolf Hitler. B/N. 1955. Medio Fílmico.

Noriega, Gustavo. Estudio crítico sobre «Los rubios». Buenos Aires: Picnic, 2009. Medio impreso.

Paranaguá, Pablo Antonio. Tradición y modernidad en el cine de América Latina. Madrid: Fondo de Cultura Económica de España, 2003. Medio impreso.

Pinto, Iván. "Chilean Film: A Brief Chronicle». ReVista. Harvard Review of Latin America, (Fall 2009/ Winter 2010). 52-54. Medio impreso.

- y Luis Horta. "Vías no realizadas en el cine político chileno. Parodia, extrañamiento y reflexividad». En Aisthesis 47 (2010). 128-141. Medio impreso.

Rancière, Jacques. Sobre políticas estéticas. Barcelona: Museu d’Art Contemporani, 2005. Medio impreso.

Restos. Carri, Albertina, dir. Act. Esteban Lamonthe, Analía Couceyro, Marta Dillon. Color.

Richard, Nelly (ed.). Políticas y Estéticas de la memoria. Santiago: Cuarto Propio, 2000. Medio impreso.

- Residuos y metáforas (Ensayos de crítica cultural sobre el Chile de la Transición). Santiago: Cuarto Propio, 2001. Medio impreso.

Salinas, Claudio y Hans Stange. Historia del Cine Experimental en la Universidad de Chile 1957-1973. Santiago: Uqbar, 2008. Medio impreso.

Spieker, Sven. The Big Archive. Art from Bureaucracy. Cambridge: MIT Press, 2008. Medio impreso.

Spiller, Roland (ed.). Memoria, duelo y narración. Chile después de Pinochet: literatura, cine, sociedad. Frankfurt: Vervuert, 2004. Medio impreso.

Vezzetti, Hugo. Pasado y Presente. Guerra, dictadura y sociedad en la Argentina. Buenos Aires: Siglo XXI, 2003. Medio impreso.

Recepción: 23 de junio de 2010

Aceptación: 19 de julio de 2010 